Bogumił Wicik

\title{
THE ORIGIN OF SALT AND SALINITY OF DRY CENTRAL MONGOLIAN STEPPES
}

The chemical properties of Central Mongolian steppes landscape have not sufficient light in geographic literature so far. Carbonate soils and weathered materials have been treated as their relict features (Nogina, 1978), while sulphate and chloride salinity has been accepted as the sign of climate aridity (Bespalov, 1951). Specific climatic features, such as large concentration of precipitation within a short period of spring which is conducive to soil washing, result, according to Glazovskaya, in the absence of gypsum precipitation in the profile of Mongolian chestnut soils (Glazovskaya, 1972).

Geographical research carried out in the years $1979-1980$ by the expedition of the Institute of Geography and Spatial Economy of the Polish Academy of Sciences let the specialists gather detailed material for the area situated about $150 \mathrm{~km}$ to the south of Ulan Bator.

The base of the expedition was in the vicinity of the town of Bayan $\left(47^{\circ} 03^{\prime} \mathrm{N}, 107^{\circ} 38^{\prime} \mathrm{E}, \mathrm{Hs}-1370\right.$, Om above sea level). The area under study (see Figure 1) borders on the Hercynian and Caledonian geological structures and is cut by the dense system of tectonic ines of such directions as: NW-SE and NE-SW (Fig. 2). Two types of morphological forms predominate there, namely wavy denudation plains as well as valleys and tectonic depressions.

The uplifted areas are made of early Mesozoic and older formations (mainly sandstones, granites; basalts and shales). Tectonic valleys are filled with the series of Jurassic carbonate rocks, terrigenous and carbonaceous (including bituminous) Cretaceous formations, and uncemented (clays and sand with boulders) Tertiary and Quaternary deposits.

The main source of sulphur in the landscapes under investigation are corbonaceous Cretaceous formations and Tertiary clayey formations. Sulphur occurs there according to oxygen-reduction conditions in the form of sulphates or sulphides. Sulphateous sulphur compounds (gypsım) are mainly found in deposits, building new regionally uplifted 
forms of the surface (horsts and suspended wings of faults), that is in the positions conducive to oxidation. In the immediate vicinity of border parts of such tectonic forms of nature, the presence of sulphate saline soils has been reported. Locally, big gypsum arystals, chemically corroded, are also found there. In such cases, the salinity of soils is there. fore connected with the east zone of rocks containing gypsum and it is the effect of chemical reactions in which calcium sulphate and mainly atmospheric water took part. The analysis of atmospheric waters from the surroundings of Bayan, Lake Cubsugul (Badrakh et al., 1976) and from the upper Kerulen basin (Michalczyk, 1979) showed that the atmospheric rainfalls of chemism type $\mathrm{HCO}_{3}-\mathrm{Na}>\mathrm{HCO}_{3}-\mathrm{Ca}>\mathrm{SO}_{4}-\mathrm{Na}$ predominate there. The effect of $2 \mathrm{NaHCO}_{2}$ (rain) $+2 \mathrm{CaCO}_{4} \cdot \mathrm{SH}_{2} \mathrm{O}$ (gypsum) reaction is sodium sulphate $\left(\mathrm{Na}_{2} \mathrm{SO}_{4}\right)$ which covers the surface of soil and gypsum fragments with white mealy deposit. The other effect of such a reaction is sparingly soluble fine crystalline calcium carbonate.

On the basis of the above-mentioned data the hypothesis can be put forward that gypsumless chestnut soils of Mongolian steppes occur in place where there exist or existed in the past conditions for periodical washing of their profile by waters of $\mathrm{HCO}_{3}-\mathrm{Na}$. In the dry steppes of Centraly Mongolia ground waters of this type of chemism were also met. (Wicik, 1981, 1983). The example described above refers to surfacesaline soils without hydromorphic features. In the lowest parts of valleys there exist lakes with water often saline with sodium sulphate. At the bottoms of some seasonal lakes, there are thickness (over $2.5 \mathrm{~m}$ ) deposits of clear and crystalline $\mathrm{Na}_{2} \mathrm{SO}_{4} \cdot 10 \mathrm{H}_{2} \mathrm{O}$. The salinity of soils in the vicinity of lakes and accumulatoin of sodium sulphate thickness deposits are in close relation with hydrological features of the area under discussion. Within the wavy denudation plains, there mainly exist fissure waters, while in tectonic valleys, clearly formed water-bearing levels are found. The primary hydrogeological system of valleys was disturbed by early Cainozoic tectonic deformations. Tectonic movements gave rise to the verticai relocation of rock mass fragments in border and central parts of valley and thus caused the differences in pressures within water-bearing levels, which led to the subartesian effects. In the places where eolian denudation strongly deepened and is deepening, the primary depression (mainly the basin of seasonal lakes), the discharge of those waters takes place, and on the surface the permanent watersheds or lakes are formed. The lakes with precipitation of crystalline sodium sulphate were found only in such valleys where water-bearing formations were i.a. organogenetic rocks (coals and bituminous shales). On the other hand, the origin of salt occurrence in them can only be 
explained by the contemporary geochemical processes which cause metamorphism of ionic composition of waters taking part in the cycle. Entering the cycle, the gravity waters, containing sodium carbonate after crossing the series of rocks with sulphur compounds disclose in the places of coming up to the surface as underground waters with increased mineralization (often over $2.7 \mathrm{~g} / 1$ ) containing a lot of sodium sulphate. The example of such an arrangement can be the surroundings of Lake Tugurig Nur (Fig. 2). The surface of salt in that periodically almost dry lakie is over $1.5 \mathrm{~km}^{2}$, and its thickness exceeds $1.5 \mathrm{~m}$. The presented graphical interpretation of the formation of the salt sodium-sulphate deposits does not seem to need further explanations. It provides grounds for drawing more general conclusions.

1. Thermal energy released in biochemical processes (Fig. 3, reaction 2), undoubtedly influences the thermic features of soils and grounds of that cryoarid surface, is conducive to deformations of its topogra-

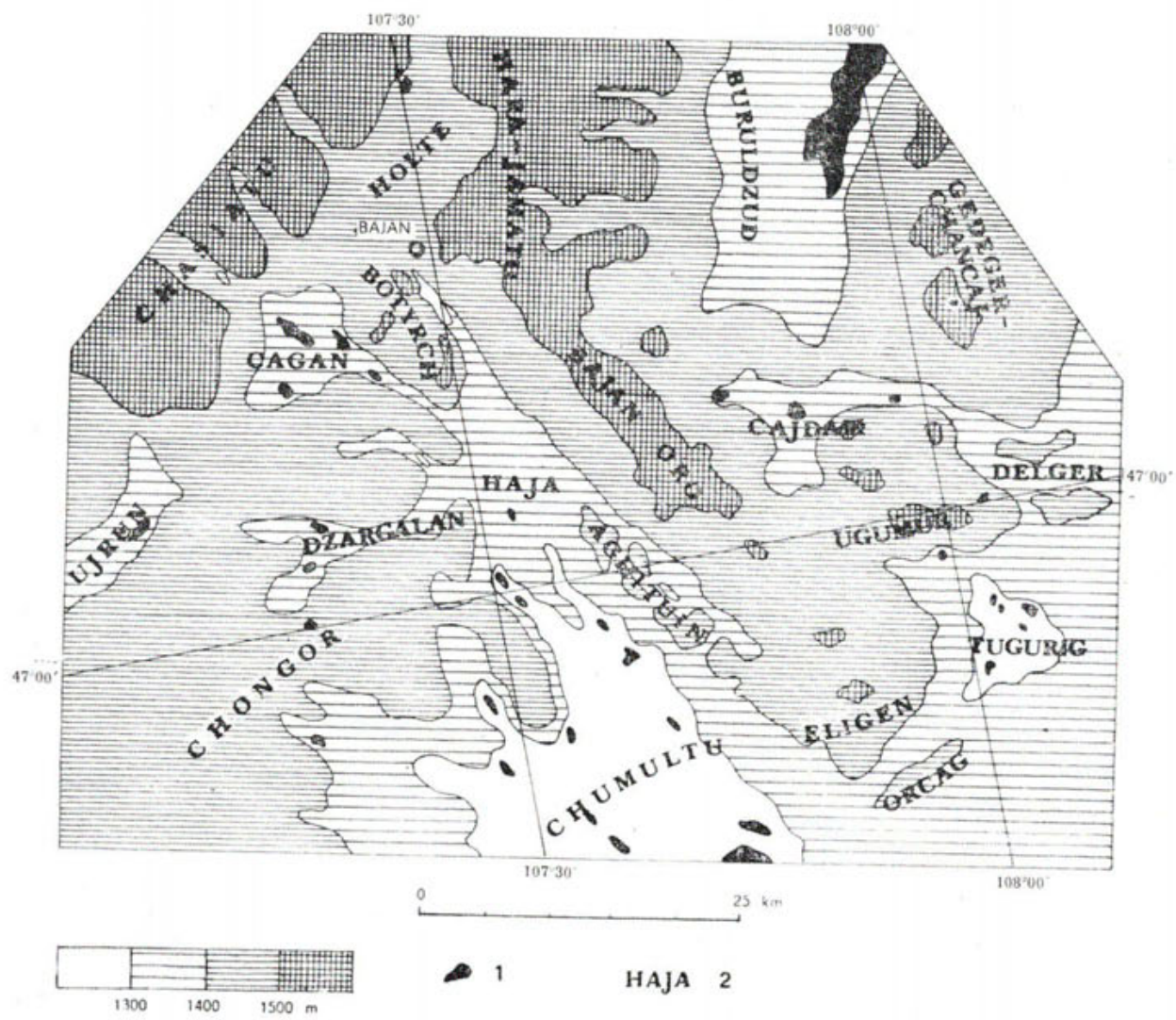

Fig. 1. The hypsametric sketch 
phy (marsh and gaseous volcanoes) and can have useful importance.

2. The releasing hydrogen sulphide (Fig. 3, reaction 2) determines not only the oxygen-reducing underground waters and soils potentially or locally strong acidifying the low level of soils (the effect of sulphide oxidation), but also the specific features of air masses in the valleys. The periodical lack of change of air in valleys may probably lead to a considerable concentration of hydrogen sulphide in the atmospheric stratum near the ground, and, as a result, to the pollution of people and animals nomadizing there.

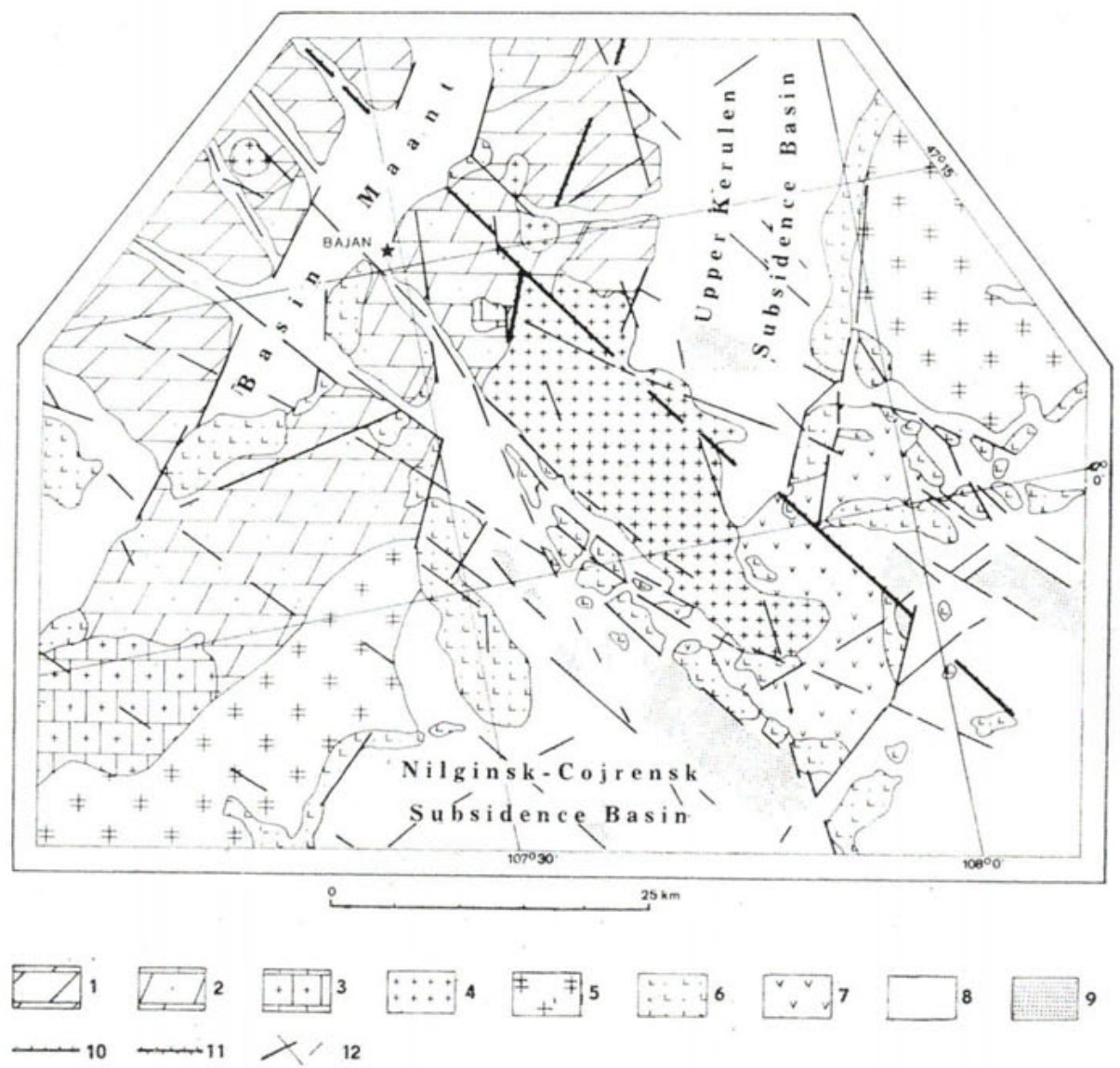

Fig. 2. Geological map

Palaeozoic and older formations 1 - metamorphic schists; 2 sandstones, conglomerates; $3-$ limestones; $4-$ granites. Triassic, Jurassic; 5 - granites, pegmatites. Jurassic, Cretaceous and younge: formations, 6- basalts; 7 - effusive acid rocks. 8 - Mesozoic and formations, formations; 9 - surfaces elevated during early-Cainosoic tectonic movements. More important tectonic lines; 10. - Choira and Chentei faults system; 11 - south Chentei faults; 12 - other tectonic lines. 
3. The sulphur and sodium compounds from the deposits formed in the lakes are the sources of salts introduced into the atmosphere by wind and take part in the soil-weathering processes of those regions of Asia.

The considerations presented above showed the important consequences of buried organic matters in the formation of chemical properties of the particular landscape unit. They have the character of natural regularities, thus making the contribution to the synthetic studies of the domain of complex physical geography. 


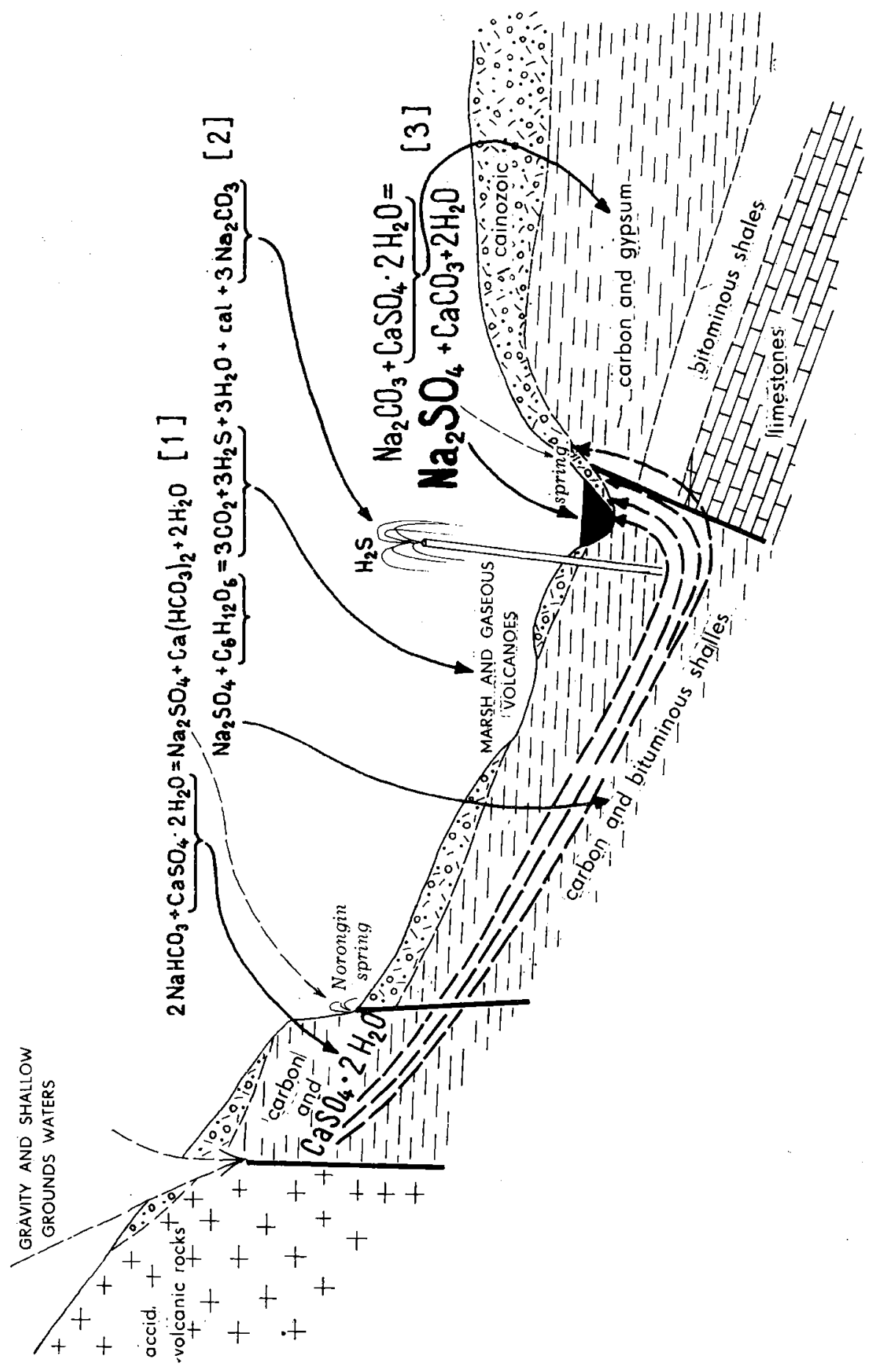

兽 


\section{REFERENCES}

Bespalov, N.D., "Pochvy Mongolskoy Narodnoy Respubliki", Trudy Mongolskoy Komisii Akademii Nauk ZSRR, vol. 42, Moskva 1951. Glazovskaya, M: A., Pochvy Mira, vol. 1 and 2, Izdatelstvo Mosk. Univ., 1972.

$\mathrm{Nog}$ in a, N. A., "O niekatorykh reliktovykh svoystvakh pochv Mongoli", in: Gienezis i geografia pochv zarubezhnych, stran, Izdat. Nauka, Moskva 1978.

Badrakh, D et al., "Khimicheski sostav atmosfiernych osadkov i povierkhnostnych vad", in: Prirodnyie uslovia i resursy Prihubugulia $v$ Mongolskoy Narodnoy Respublike, Niedra, Moskva 1976, p. 207-229.

M icha 1 czyk, Z., "Właściwości fizyrczno-chemiczne wody i denudacja chemiczna w dorzeczu Dunda Badałag" (Physico-chemical Properties of Water and Chemical Denudation of River Basin of Dunda Badalag) in: Raport Mongolsko-polskiej ekspedycji fizyczno-geograficznej Transmongolia 78. [Report of Mongolian-Polish Physico-geographical Expedition Transmongolia 78.] Instytut Geografii i Przestrzennego Zagospodarowania PAN, Kraków 1979 (typescript).

Wicik, B., "Hydrogeochemia stepów Srodkowej Mongolii" (Hydrogeochemistry of Central Mongolian Stepps), Przeglad Geofizyczny XXVI, 3, 1981, p. 131$-142$.

Wicik, B., "Geochemical Properties of Landscapes" in: Mongolian Dry Steppe Geosystems. A Case Study of Gurvan Turuu Area. Geographical Studies, Special Issue, Ossolineum Wroclaw 1983, p. 46-56. 
